\title{
EXAMINING THE RURAL TOURISM EXPERIENCES OF TOURISTS IN EMERGING RURAL TOURISM DESTINATION: BURDUR PROVINCE, TURKEY
}

\author{
Bayram AKAY* \\ Burdur Mehmet Akif Ersoy University, School of Tourism and Hotel Management, \\ İstiklal Yerleşkesi, p.k. 15030/ Burdur, Turkey, e-mail: bakay@mehmetakif.edu.tr
}

\begin{abstract}
Citation: Akay, B. (2020). EXAMINING THE RURAL TOURISM EXPERIENCES OF TOURISTS IN EMERGING RURAL TOURISM DESTINATION: BURDUR PROVINCE, TURKEY. GeoJournal of Tourism and Geosites, 29(2), 534-544. https://doi.org/10.30892/gtg.29212-487
\end{abstract}

\begin{abstract}
This study examines the rural tourism experiences of the tourists visiting the Lake Salda and Lisinia Doğa of Burdur province, which has shown an important development in rural tourism in recent years. Data has been collected from the comments of the tourists who have visited Lake Salda and Lisinia Doğa on the online platform www.tripadvisor.com and content analysis has been used to examine data. Frequency and word cloud analysis have been performed in MAXQDA Analytics Pro program. Research results indicate that rural tourism experiences are versatile and heterogeneous, based on authentic (unique) experience, activity experience, local food \& beverage experience, accommodation experience, local souvenir experience, testify wildlife rehabilitation, transportation experience and negative experience. Tourism businesses may be offered to design and manage their products and services for rural tourism experiences.
\end{abstract}

Key words: rural tourism experiences, emerging rural tourism destination, Burdur, Turkey

\section{INTRODUCTION}

Burdur province is located in the transition area from the Mediterranean Region to the Aegean and Central Anatolian Regions in the region of the Mediterranean region of Burdur and in the region called Lakes Region, at $29^{\circ}-24$ 'and $30^{\circ}-53^{\prime}$ Eastern Longitudes and $36^{\circ}-53$ 'and $37^{\circ}-50^{\prime}$ Northern Latitudes. Burdur is surrounded by Antalya in the South, Denizli in the West, Muğla in the Southwest, Isparta and Afyon in the East and North (Balc1 et al., 2018). Burdur is of importance in terms of rural tourism activities with its location hosting natural, historical and cultural tourism values on the route transitioning from Mediterranean Region to Aegean Region and to the hinterlands of our country at the region called "Lakes Region" on the roads leading to Denizli-Antalya-Muğla provinces where the important touristic centers of Turkey are located (Temurçin et al., 2019). With the influence of social media in recent years, Burdur has become an

\footnotetext{
* Corresponding author
}

http://gtg.webhost.uoradea.ro/ 
important destination showing rural tourism development. Tourism in the province has grown significantly, from approximately 12,394 visitors in 2010 to approximately 36,288 visitors in 2018 (Ministry of Culture and Tourism, 2019). The natural, historical and cultural values of Burdur province play a role in this development.

For example, the best preserved Sagalassos ancient city of Anatolia was included in the UNESCO World Heritage Temporary National List in 2009 and the ancient city of Kibyra in 2016 (Burdur Provincial Directorate of Culture and Tourism, 2020). Lake Salda, with white sands and turquoise waters, began to be known as the Maldives of Turkey. Lisinia Doğa is a micro rural tourism destination resulting from different projects focused on solutions to social, environmental and economic problems (Erbaş, 2019). In addition, due to the fact that lavender gardens in the Lakes Region (Isparta and Burdur provinces) have attracted the attention of tourists in recent years, the Lavender Stream Project in Yeşilova's Akçaköy Village has turned into a touristic product in which local people make economic gains within the scope of rural tourism activities (Temurçin, 2019: 47).

Studies on experience in tourism literature, regardless of tourism types, are observed under tourism/tourist experience (Pine \& Gilmore, 1998; Jackson et al., 1996; Prentice et al., 1998; Li, 2000; Oh et al., 2007; McIntosh \& Siggs, 2005; Altunel \& Erkut, 2015). Knowing the experiences for different types of tourism will not only increase the satisfaction of the tourists, but also will provide tourism companies with products and services for the experiences. Tourism companies will do their job, package tour and sales according to these experiences. The aim of the research is to examine and understand the rural tourism experiences of travelers who visit Salda Lake and Lisinia Doğa located in Burdur province in the Lakes Region of Turkey.

\section{LITERATURE REVIEW}

\section{Rural tourism and its experience}

Rural tourism is defined as the presence of people in natural environments, rest and the desire to be together with people with different cultures, to go to rural settlements and stay in accommodation businesses specific to the places, to taste the foods and drinks of that region, to discover and experience the abstract and concrete culture of that region. (Soykan, 2001). Rural tourism is a type of tourism based on natural resources, intertwined with rural settlements (Uslu et al., 2015: 352). Rural tourism is preferred by middle-aged and middle-income, educated, professional professionals and those traveling with family (Soykan 2003, Ongun et al., 2016: 78). In the literature, studies related to tourism / tourist experience are encountered rather than rural tourism experience. Pine \& Gilmore, 1998 (unique, emotionally charged, and of high personal value); Jackson et al., 1996; Prentice et al., 1998; Li, 2000 (understand tourist experiences from a number of perspectives); Oh et al., 2007; McIntosh \& Siggs, 2005; Altunel \& Erkut, 2015 (education, entertainment, esthetics, escapism). Kim et al. (2016) have discussed tourist experience in price, service, atmosphere, overall customer evaluation and food dimensions.

According to Doğan et al. (2016), the tourist experience is the dimensions of atmosphere, price, cleanliness, food, service and staff. Bayram et al. (2017), on the other hand, have examined the image of destination, tourist attractions, natural environment, public, special events, culture and art, infrastructure, transportation, accommodation, information, food and beverage, pleasant, exciting, refreshing and relaxing experience. İnanır et al. (2019), has examined the experiences of Cittaslow tourists in terms of nature and scenery, local products, regenerative facilities, hospitality, tourism businesses, publicity (knowledge), neglect/indifference/pollution (environment), perceived service quality and price. İnanır and Ongun (2019) has examined the experiences of Yeşilova 
Lake Salda visitors positively and negatively. The positive experience dimension is natural structure, health, recreational activities, local people, geographical location and gastronomy; the negative experience dimension is the environment, infrastructure and superstructure, information and perceived service quality.

According to the World Tourism Organization, 2004), rural tourism is composed of four main components in which rural communities are located in the center. These are rural areas (mountains, lakes, rivers, forest, natural areas), rural heritage and culture (traditional and industrial architecture, historical buildings, villages), rural activities (ride a horse, biking, fishing, walking, water sport) and rural life (handcraft, local activities, local foods, farm tourism, traditional music, folk dances) (Figure 1).

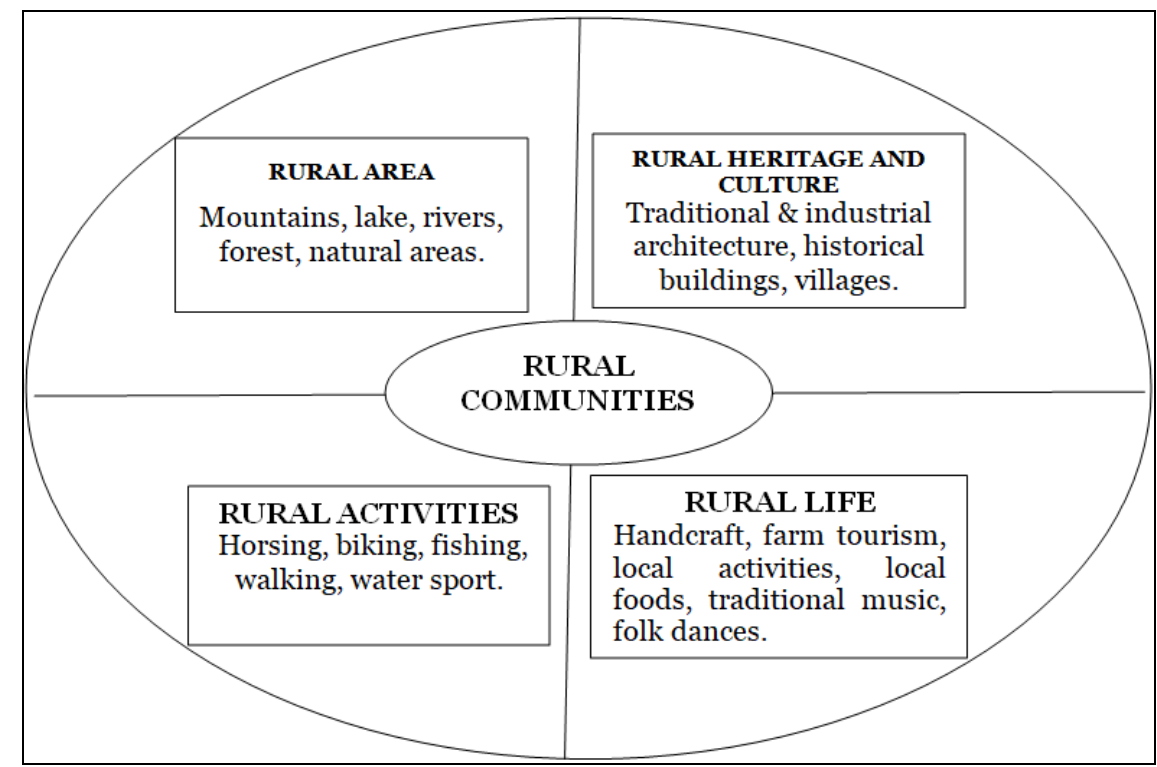

Figure 1. Components of Rural Tourism (Source: World Tourism Organization, 2004)

\section{Burdur as an emerging rural destination: Lake Salda and Lisinia Doğa}

Lake Salda is a tourist value with significant rural tourism potential, which has attracted domestic and foreign tourists in recent years. Lake Salda has attracted the attention of tourists who want to explore different places and be in touch with nature with its national and international recognition. As a result, the number of tourists coming to the district has increased considerably (Temurçin et al., 2019: 48).

Lisinia Doğa is a micro rural tourism destination established in 2005 in the city of Burdur (known as region of lakes). With the time, Lisinia Doğa visited by tourists. The tour operators have developed package tours (i.e., region of lake tours) including Lisinia Doğa (Erbaş, 2019: 2405). Lake Salda is located at Lakes Region of Turkey, about $64 \mathrm{~km}$ west of the province of Yeşilova district boundaries. The lake has a formation consisting of rocks that are resistant to abrasion and can easily melt. It is a tectonic formation of the Lake Salda formation that occurs between the Late Miocene and Early Pliocene approximately 5 million years ago and is still active (Sert et al, 2018: 656). Despite being Turkey's deepest lake, Lake Salda is called the "Maldives of Western Anatolia" or "Saldives" due to the clarity of its waters. Its height above sea level is $1.140 \mathrm{~m}$. Its surface area is $44 \mathrm{~km}^{2}$. The lake is located on the Antalya-Denizli Pamukkale main-tour route, 
where tourism is intense during the summer and winter months (Burdur Provincial Directorate of Culture and Tourism, 2011: 47). Lake Salda is one of the most generous areas of nature, offering alternative holiday opportunities with its beach, beautiful scenery in turquoise color, clean nature, forests and camping sites. It is home to many bird species. Lake Salda offers opportunities such as sailing, canoeing, windsurfing, photosafari, lake tour, fishing, underwater diving, swimming (Ongun et al., 2016). Lake Salda consists of three different areas: White Islands, Lake Salda Nature Park, Lake Salda Municipality and Doğanbaba Beach. Lake Salda Natural Park was visited by 6,596 in 2013, 34.829 in 2014, 20,995 in 2015, 36,979 in 2016 and 67,115 in 2017 (Table 1).

Table 1. Number of tourists visiting Lake Salda Nature Park (2013-2017)

\begin{tabular}{|l|l|l|l|l|}
\hline $\mathbf{2 0 1 3}$ & $\mathbf{2 0 1 4}$ & $\mathbf{2 0 1 5}$ & $\mathbf{2 0 1 6}$ & $\mathbf{2 0 1 7}$ \\
\hline 6,596 & 34,829 & 20,995 & 36,979 & 67,115 \\
\hline
\end{tabular}

Source: Burdur Provincial Directorate of Culture and Tourism, 2020

As of 2018, statistics for these three different areas have been kept. In 2018, a total of 689,730 people visited Lake Salda, with 292,000 people visiting White Islands, 97,730 people visiting Lake Salda Natural Park, and 300,00o people visiting Lake Salda Municipality and Doğanbaba Beach. In 2019, a total of 1,079,658 people visited Lake Salda, with 734,505 people visiting White Islands, 122,031 people visiting Lake Salda Natural Park, and 223,122 people visiting Lake Salda Municipality and Doğanbaba Beach (Burdur Provincial Directorate of Culture and Tourism, 2020).

Table 2. Number of tourists visiting Lake Salda (2018-2019)

\begin{tabular}{|c|c|c|c|c|}
\hline Years & $\begin{array}{c}\text { White } \\
\text { Islands }\end{array}$ & $\begin{array}{c}\text { Lake Salda } \\
\text { Nature Park }\end{array}$ & $\begin{array}{c}\text { Lake Salda Municipality } \\
\text { and Doganbaba Beach }\end{array}$ & Total \\
\hline 2018 & 292,000 & 97,730 & 300,000 & 689,730 \\
\hline 2019 & 734,505 & 122,031 & 223,122 & $1,079,658$ \\
\hline
\end{tabular}

Source: Burdur Provincial Directorate of Culture and Tourism, 2020

There is a total of 41 accommodation facilities in Burdur with 14 Ministry Certificate and 27 Municipality Certificate (Ministry of Culture and Tourism, 2019). With the development of tourism in Lake Salda, there are a total of 21 2-3-star hotels, pensions and apart hotels, of which 11 were opened in 2019, 5 in 2018 and 5 in previous years. These accommodation facilities have 182 rooms and 493 beds capacity (Temurçin, 2019: 47). Öztürk Sarıca, a veterinarian and a volunteer of nature, established a village named Nature Based Wildlife Protection and Rehabilitation Center (Lisinia Doğa) in 2005 within the borders of Burdur Karakent Village (Ongun et al., 2015: 107). The project, which was launched in 2005, has realized nearly 1,000 subprojects under 9 project titles so far. Nearly 20 of them are still active. Projects prominent among them are: a wildlife rehabilitation center, free nature camps, lavender gardens, ecological fields in Lisinia (https://www.lisinia.com/tr/projeler).

It is possible to carry out activities such as photography, trekking, camping, cycling, horse riding and lavender care in Lisinia Wildlife Village. Activities carried out in this center are carried out on a voluntary basis (Ongun, 2017: 139). Volunteers stay in rooms for 3 or 4 people free of charge. While Lisinia does not charge volunteers for nature shelter and nutrition, volunteers support production in return. Lisinia Doğa hosted 120,000 visitors between 2005 and 2017, 200,000 in 2018 and 300,000 visitors and more than 5,000 foreign volunteers in 2019 (https://www.sabah.com.tr). 


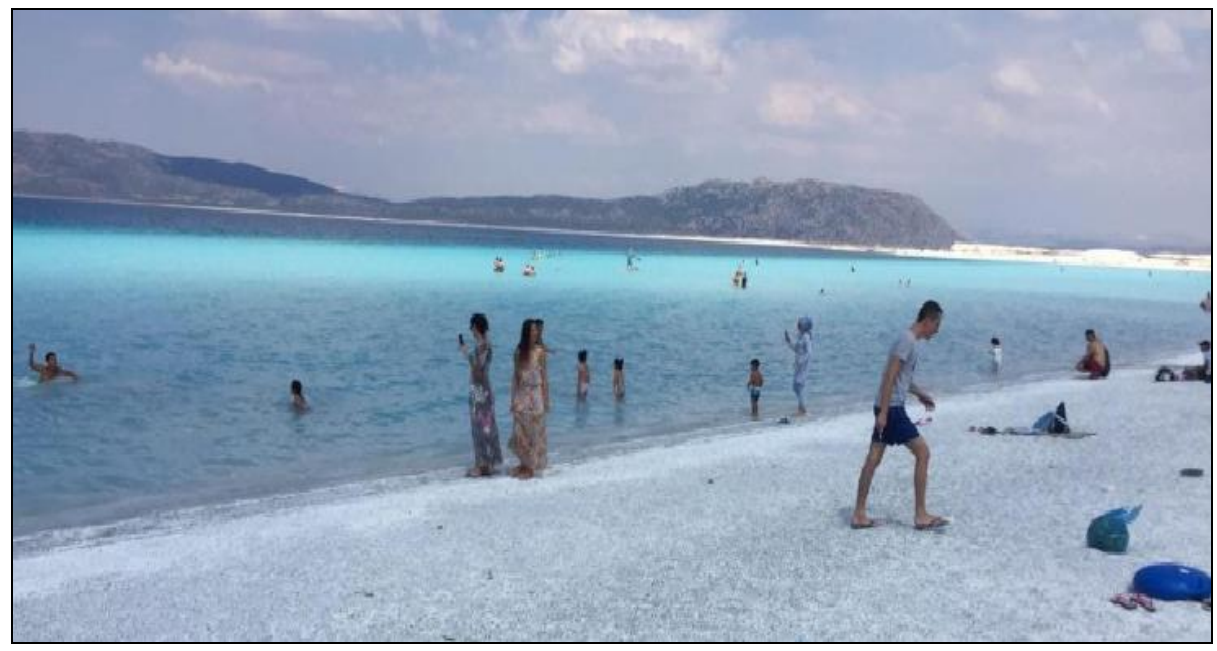

Figure 2. Lake Salda

\section{Dimensions of the tourist experiences}

Before moving on to the tourist experience dimensions, it is beneficial to explain the concept of "phenomena". In literal sense, is called the study of "phenomena": appearances of things, or things as they appear based on our experiences, or the forms which things take when we experience them, in other words, the meaning of things within our experience, is called phenomenology. It is the study of the structures of consciousness experienced from the point of view of the first person: „Me”. A wide range of types of experiences including the perception, thought, memory, imagination, emotion, wishing and strength of will, are studied as well as physical action, social action and the linguistic activity in case of the involvement physical consciousness. An experience is directed at an object based on its content or meaning (what the objects represent, also historically) along with the suitable conditions that apply (http://www.tourismtheories.org/? $\mathrm{p}=1503$ ).

Researching the tourism/tourist experience in the tourism literature, Cohen (1979: 180) notes that tourist experience will not be generally accepted and people with different traits may desire different types of tourist experiences. Cohen (1979: 183) suggested five different tourist modes ( recreational mode, diversionary mode, experiential mode, experimental mode, existential mode) based on the religion sociology and tourism sociology for tourist experiences. The first two modes of tourist experiences (recreational and diversionary) refers to the persons travelling with the motivation of spending a good time and escaping the facts, while the remaining three modes (experiential, experimental, existential) points to the persons motivated with the search for uniqueness on various levels (Sağıroğlu, 2019: 92). Cohen (1994) has defined the tourists as explorers, drifters, elite, extraordinary, organized mass tourist and individual mass tourist based on the level of uniqueness they pursue, while Plog (2001) has defined them as adventurous and extrovert. The common ground for all these tourist types is the fact that they are adventurous and open to new things, participate actively, keep the excitement and energy high and they seek experiences outside an ordinary tourist (Polat \& Polat, 2016:249).

\section{MATERIALS AND METHODS}

The comments shared by tourists have become one of the most important sources not only for travelers but also for tourism businesses due to the rapid development of 
internet and social media usage. Online comments and forums, travel blocks, websites, social media sites are also common methods of data collection for researchers (Bayram et al., 2017; Kim et al., 2016; Doğan et al., 2016; Zhou, 2014). In this research, 920 Lake Salda comments at www.tripadvisor.com between 2013-2019 and 30 Lisinia Doğa comments between 2017-2019 have been analyzed by different steps.

In the research, the comments at www.tripadvisor.com were carefully read and each comment was recorded by giving the order number to Excel. Then, the data has been transferred to the MAXQDA Analytics Pro 2018 qualitative data analysis program and frequency and word cloud analysis has been performed. As a result of frequency analysis, content analysis has been made from the most frequently repeated words.

\section{RESULTS DISCUSSIONS}

When the content analysis of 920 visitors visiting Lake Salda is made, it is observed that tourists have many rural experiences (Table 3). First, it is clear from the travelers' comments that authentic experiences (wonderful atmosphere, sunset, azure, white rocks, white beach, unspoilt nature, turquoise beauty, clay mask, blue see, watched the landscape, Maldives, Saldiv's, wonderful nature, beautiful lake) of Lake Salda are significant factors that affect their experiences. Activity experiences (swimming, picnic, camping, taking photos, kayaking, bicycling, visiting the village) are another important experience emphasized by travelers. In the literature, activities in rural areas are considered to be one of the key aspects of rural tourism experience (Ongun et al., 2016; Popp \& McCole, 2016; Crowley et al., 2015). At Burdur, Yeşilova, Lake Salda and its surroundings, due to tourist mobility, pancake, diced lamb fried on iron plate, Yeşilova minced meat toast, pita, restaurant, coffee house and snack bars that make pita with tahini are the food and beverage experience of the travelers. Comfortable bungalows, boutique hotels, camps around the lake, family and eco-friendly hotels provide accommodation experience. Dickinson \& Robbins (2008) stated that tourists prefer rural hotels, hostels, boutique hotels, camps, rural houses and apartments in rural areas. The absence of 4-5-star hotels in the region increases the preferences of rural tourists.

The souvenirs which are part of the tourists' destination experience (Akay \& Yllmaz, 2019), natural products such as walnut paste, walnut, grape, souvenir shop, village grocer, small shop for shopping. Tourists buy souvenirs and products that are specific to the region they go to in order to remind them of their travels (Cave et al., 2012). While the tourists visiting Lake Salda are pleased with the availability of shuttle bus, tours of travel agencies and different highways, those coming notedly with personal vehicles are disturbed due to non-stable, broken roads and poor village roads. Page (2005) has emphasized that transportation in tourism can be an attraction in itself as it offers a high tourism experience to tourists, Popp \& McCole (2016) has emphasized that private car transportation to rural destinations is an important part of the tourism experience and Dickinson \& Robbins (2008) has emphasized the transportation problems in rural destinations. Burdur-Yeşilova highway construction started in 2017 and hot asphalt and new traffic signs have been commissioned at the beginning of 2019. The problems may arise before and during the road construction works.

Tourists coming to Antalya, an important coastal tourism destination (more than 15 million tourists in 2019) and Denizli with Pamukkale travertines (thermal spring)Hierapolis ancient city (more than 3 million tourists in 2019) also visit Lake Salda individually or with tours. As a -location, Lake Salda is $2 \mathrm{~km}$ to Yeşilova district, $64 \mathrm{~km}$ to Burdur centrum, $86 \mathrm{~km}$ to Denizli Çardak Airport, $98 \mathrm{~km}$ to Isparta Süleyman Demirel Airport and $140 \mathrm{~km}$ to Antalya Airport. Travelers request the central administration 
(Government Authority), Ministry of Agriculture and Forestry, Ministry of Culture and Tourism to protect Lake Salda and its surroundings, and the permanence of the restaurant, bungalow and beach services of the municipality (Municipality Authority).

Tourists have warned against the disruption of natural beauty of the Lake Salda, deterioration compared to previous years, garbage and environmental pollution within the area. Activities above the carrying capacity of the lake and its surrounding significantly affect the lake, which has very sensitive features (Kesik et al., 2018: 8). In cases where the carrying capacity is exceeded, the growth of the destination stops and even a rapid decline starts with the deteriorated image (Türkay \& Kahraman, 2009; 65). Since Lake Salda is usually visited by excursionists, visitor management, natural heritage conservation and sustainability should be taken into consideration in the coming years.

Table 3. Experience of tourists visiting Lake Salda

\begin{tabular}{|l|l|}
\hline \multicolumn{1}{|c|}{ Dimension } & \multicolumn{1}{c|}{ Sub-Dimension } \\
\hline $\begin{array}{l}\text { Authentic (Unique) } \\
\text { Experience }\end{array}$ & $\begin{array}{l}\text { Maldives, Saldiv's, Wonderful Atmosphere, Sunset, Azure, Crystal Clear } \\
\text { Lake, White Rocks, White Beach, Unspoilt Nature, Turquoise Beauty, Clay } \\
\text { Mask, Blue See, Watched the Landscape, Wonderful Nature, Beautiful Lake. }\end{array}$ \\
\hline Activity Experience & Swimming, Picnic, Camping, Take Photos, Kayaking, Bicycling, Visit the village \\
\hline $\begin{array}{l}\text { Local Food \& } \\
\text { Beverage Experience }\end{array}$ & $\begin{array}{l}\text { Turkish Gözleme, Saç Kavurma (diced lamp fried on iron plate), Famous } \\
\text { Yeşilova Toast, Pita with tahini, Small Restaurant, Coffeehouse, Snack Bar. }\end{array}$ \\
\hline $\begin{array}{l}\text { Accommodation } \\
\text { Experience }\end{array}$ & $\begin{array}{l}\text { Comfortable Bungalows, Boutique Hotel, Small Hotel, Salda Forest Camp, } \\
\text { Family Hotel, Eco-friendly Hotel. }\end{array}$ \\
\hline $\begin{array}{l}\text { Local Souvenir \& } \\
\text { Shopping Experience }\end{array}$ & $\begin{array}{l}\text { Natural Product (Walnut Paste, Walnut, Grape), Souvenir Shop, Village } \\
\text { Grocer, Small Shop. }\end{array}$ \\
\hline $\begin{array}{l}\text { Transportation } \\
\text { Experience }\end{array}$ & $\begin{array}{l}\text { Adequate Park Area, Shuttle Bus from Burdur, tour group, by Private Car, by } \\
\text { Plane, Excursion, Asphalt Road, Poor Road, Stabilized Road, Willage Road, } \\
\text { Dusty Road, Bad Road, Handle Road, Lightless Road, Mountain Road, } \\
\text { Smooth Road, Fatigue Road, New Road. }\end{array}$ \\
\hline Location & $\begin{array}{l}\text { Salda Natural Conservation Area, 2 km From Yeşilova, 64 km from center } \\
\text { of Burdur, From Denizli Çardak Airport 86 km, From Isparta Süleyman } \\
\text { Demirel Airport 98 km, From Antalya Airport 140 km. }\end{array}$ \\
\hline $\begin{array}{l}\text { Government \& } \\
\text { Municipality } \\
\text { Authority }\end{array}$ & $\begin{array}{l}\text { Forest Ministry. Tourism Ministry restored, care, protected, regulation, } \\
\text { Municipality's Restaurant, Municipality bungalows Municipality Public } \\
\text { Beach, Missing Signage }\end{array}$ \\
\hline Negative Experience & Natural Impairment, Waste, Crowded, Pollution. \\
\hline
\end{tabular}

In Figure 3, a word cloud is given from 75 words mentioned at least 30 times out of 69,072 words collected under the themes resulting from the codes above. When creating a word cloud, words such as, for, but, and, are not included in the analysis. When Figure 3 is examined; the words related to authentic experience (Maldives, clay, white, beach, blue, see, nature, sand, turquoise), activity experience (swim, picture, photos, raft, camp, tent, salda), local food \& beverage experience (restaurant, eat, food), accommodation experience (stay, night, tent, camp), transportation experience (car, road, bad, visit), location (Turkey, Burdur, Antalya, Salda), government \& municipality authority (municipality, public, facilities), negative experience (garbage, crowded, environment) stand out. This word cloud is the validation (testing) of the dimensions and sub-dimensions that make up travelers' Lake Salda experiences in Table 3.

Table 4 shows the different experience dimensions of those who visit Lisinia Doğa. First of all, travelers have activity experience such as photography, trekking, camping, cycling, horse riding, lavender care, volunteer staff and visiting the Village. 
Authentic (unique) experience such as natural products, natural beauties, wooden houses, wooden statuary, unique views are another important experience by travelers.

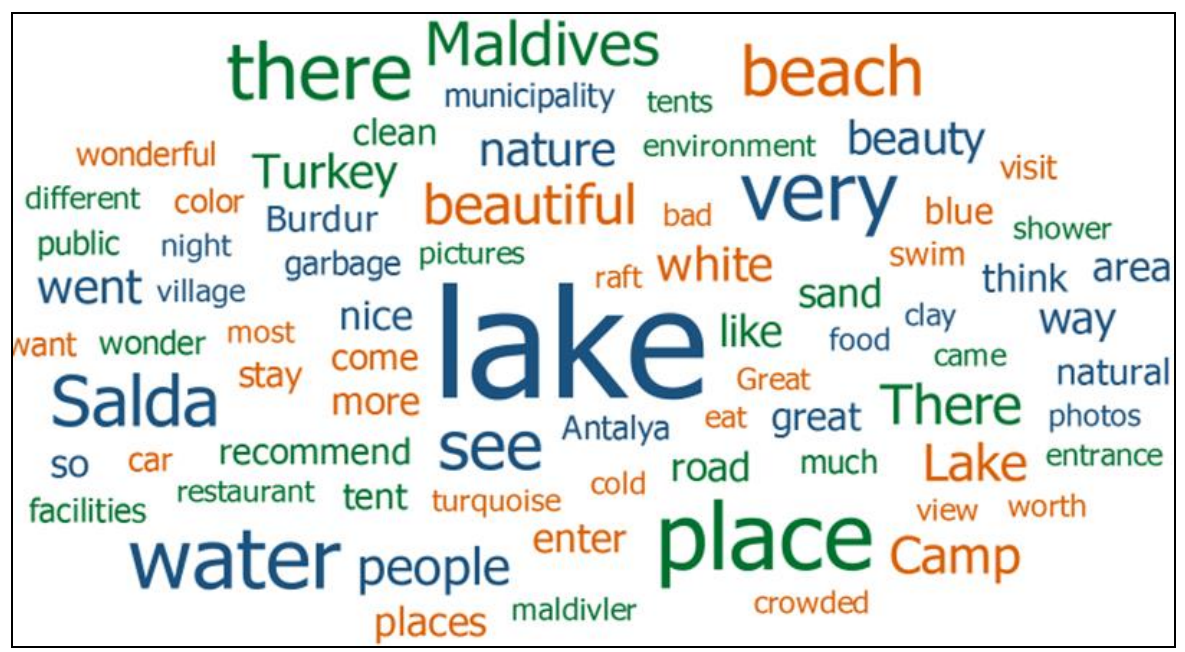

Figure 3. Word Cloud based on Lake Salda visitor reviews

Table 4. Experience of tourists visiting Lisinia Doğa

\begin{tabular}{|l|l|}
\hline \multicolumn{1}{|c|}{ Dimension } & \multicolumn{1}{c|}{ Sub-Dimension } \\
\hline Activity Experience & $\begin{array}{l}\text { Photography, trekking, camping, cycling, horse riding and } \\
\text { lavender care, visit the Village, work in the projects as volunteer. }\end{array}$ \\
\hline $\begin{array}{l}\text { Authentic (Unique) } \\
\text { Experience }\end{array}$ & $\begin{array}{l}\text { Natural products (organic and edible cosmetics, medicinal liquids, } \\
\text { soaps, colognes, peony, lavender-rose oil), natural beauties, } \\
\text { wooden houses, wooden statuary, unique views. }\end{array}$ \\
\hline $\begin{array}{l}\text { Local Food \& Beverage } \\
\text { Experience }\end{array}$ & $\begin{array}{l}\text { Local product, Burdur shish kebab, lavender tea, ayran, Turkish } \\
\text { gözleme, honey, and concentrated food. }\end{array}$ \\
\hline $\begin{array}{l}\text { Testify Wildlife } \\
\text { Rehabilitation }\end{array}$ & $\begin{array}{l}\text { Wild life, injured animals, animal care, stork, wolf, swine, eagle, } \\
\text { partridge. }\end{array}$ \\
\hline Accommodation Experience & Hotel, Camp, pension, bungalows. \\
\hline Location & $\begin{array}{l}\text { Near the Burdur Lake, 25 km from center of Burdur, 120 km from } \\
\text { Denizli Çardak Airport, 38 km from Isparta Süleyman Demirel } \\
\text { Airport, 130 km from Antalya Airport. }\end{array}$ \\
\hline
\end{tabular}

Local food \& beverage (local products, Burdur shish kebab, lavender tea, ayran, pancakes, honey, and concentrated food) are experiences for travelers. While the tourists are making their vacation plans, they also consider food and beverages along with the subjects such as the nature and historical structure of the destinations (Mak et al., 2012: 172). Some travel for gastronomic experience and request a gastronomic guide for local food and beverage experiences (Akay \& Özöğütçü, 2019). One of the founding goals of Lisinia Doğa is the rehabilitation of wild animals. Testify wildlife rehabilitation; animals shot by hunters, poisoned by chemicals and diseased ones, is retreated and reintroduced to their natural environment. Hotel, camp, hostels, bungalows create the accommodation experience. In addition, the food and accommodation need of the volunteers who help daily jobs are meet free of charge. As a -location, it is near the Burdur Lake, $25 \mathrm{~km}$ from center of Burdur, $120 \mathrm{~km}$ from Denizli Çardak Airport, $38 \mathrm{~km}$ from Isparta Süleyman Demirel Airport, $130 \mathrm{~km}$ from Antalya Airport. Lisinia Doğa is 
very close (1.5-2.5 hours) to the main tourist destinations (Antalya and Muğla 15 million visitors in 2018) in Turkey (Erbaş, 2019: 2409). In Figure 4, a word cloud is given from 28 words mentioned at least 5 times out of 1,236 words collected under the themes resulting from the codes above. Words such as natural, products, animals, place, wild, lavender, Burdur, lake, oil, nature, life, country, see, area in the word cloud highlight the rural areas of Lisinia. It is understood from the words like beautiful, many, great, value, stop, need and how much the visitors of this center are affected.

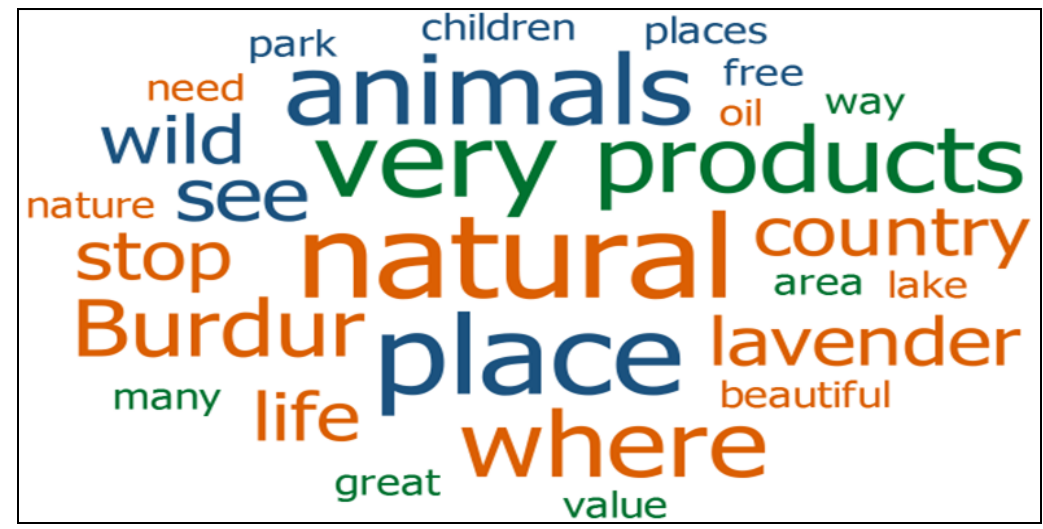

Figure 4. Word Cloud based on Lisinia Doğa visitor reviews

\section{CONCLUSION}

Lake Salda was discovered within the last decade with the effect of social media (Instagram, Facebook, Twitter, Travel Sites) with its magnesium-containing white rocks and beach, clean, turquoise blue color and began to receive a high number of visitors. Lake Salda trended many times on Twitter, had 74,900 related posts on Instagram, thousands of posts on Facebook and 920 comments on TripAdvisor. It started to be known as the Maldives of Turkey and Saldives. Established in 2005 by veterinarian and volunteer Öztürk Sarıca, Lisinia Doğa is an initiative that presents different projects focused on solutions to social, environmental and economic problems (future without cancer, nature school, ecological production). Lisinia Doğa has made its mark on social media and various platforms by animal lovers, nature lovers, volunteer tourism professionals, people who have migrated from the village to the city and escaped from city stress, tourists looking for new experience. The experiences of tourists visiting Lake Salda can be defined as versatile and heterogeneous based on authentic (unique) experience, activity experience, local food \& beverage experience, accommodation experience, local souvenir experience, transportation experience and negative experience. Tourists visiting Lisinia Doğa get activity experience, authentic experience, local food \& beverage experience, testify wildlife rehabilitation, accommodation experience.

Different rural tourism experience dimensions such as authentic (unique) experience, activity experience, local food experience, accommodation experience, local souvenir experience, wildlife experience come to the fore in Burdur as an emerging rural destination. These dimensions provide tourists with experience on these qualities and features in the destination (Çetinkaya, 2017: 113). Experience specific to Lake Salda and Lisinia Doğa are important points that tourism businesses should focus on.

Recreation enterprises from tourism enterprises should focus on swimming, photography, horseback riding, water sports, camp; food and beverage establishments 
should focus on local delicacies such as pancake, roasting, minced meat, toast, with tahini pita, and local dishes such as Burdur Shish Kebab; accommodation enterprises should focus on small hotel, pension, apart hotel, boutique hotel, camp, bungalow; souvenir businesses should focus on different products such as natural product (walnut paste, walnut, grape, lavender, lavender tea, lavender oil, rose product). It can be recommended to the managers of existing tourism enterprises to improve their service quality for these experiences and to start new businesses according to these experiences. In addition, for the development of Burdur province as a rural tourism destination, it should establish a destination management organization consisting of public and private sector, universities and non-governmental organizations and undertake the protection, use and promotion activities of the destination. In future researches, a survey can be created from these research dimensions and applied to visitors. Rural tourism experiences can be compared in different rural tourism destinations. Reviews of ancient cities of Sagalassos, Kibyra, Kremna can be examined as cultural tourism destinations experience. The research is expected to be a guide for rural tourism experience research, rural administrators (government \& municipality authority) and rural tourism operators.

\section{REFERENCES}

Akay, B. \& Özögütçü, B. (2019). Effects of gastronomy knowledge and perception of tourist guides on intention of recommendation. MANAS Journal of Social Studies, year 8, no.1, vol: 8, p. 1451-1463.

Akay, B. \& Yllmaz, O. (2019). A research on the travel motivations of tourist and their behavior on purchasing sonivenirs. MANAS Journal of Social Studies, year 8, no.2, vol: 8, p. 2163-2186.

Altunel, M.C. \& ve Erkut, B. (2015). cultural tourism in istanbul: the mediation effect of tourist experience and satisfaction on the relationship between involvement and recommendation intention. Journal of Destination Marketing \& Management, year 4, no. 4. vol 4, p. 213-221.

Balc1, N., Demirel, C. \& Kurt, M.A. (2018). Geomicrobiology of lake salda and microbial influences on presentday stromatolite formation. Bulletin of the Earth Sciences Application and Research Centre of Hacettepe University, year 20, no. 1, vol 39, p. 19-40.

Bayram, M., Bayram, Ü. \& Kara, M. (2017). Evaluation of the Kyrgyzstan online destination image. 3rd International Symposium of the Turkish World, 20-22 April 2017, Kyrgyzstan, p. 476-485.

Cave, J., Jolliffe, L. \& Coteau, D.D. (2012). Mementos of place: souvenir purchases at the bridgetown cruise terminal in Barbados, tourism. Culture \& Communication, year 12, no. 19 vol 12, p. 39-50.

Çetinkaya, Ö. (2017). Cruise tourists' experiences, satisfaction and behavioral intentions: a case study in Istanbul. Journal of Business Research-Türk, year 8, no. 2, vol 9, p. 110-132.

Crowley, M. Lichter, D.T. \& Turner, R.N. (2015). Diverging fortunes? Economic well-being of Latinos and African Americans in new rural destinations, Social Science Research, vol 51, p. 77-92.

Cohen, E. (1996). A phenomenology of tourist experiences, in: The sociology of tourism: theoretical and empirical investigations, (edts: Yiorgis A., Stella L, Andrew Y), Routledge: London, U.K. p. 90-111.

Cohen, E. (1979). A phenomenology of tourist experiences. Sociology, year 7, no. 2, vol 13, p: 179-201.

Dickinson, J.E. \& Robbins, D. (2008). Representations of tourism transport problems in a rural destination. Tourism Management, vol 29, p. 1110-1121.

Doğan, S., Güngör, M.Y. \& Tanrıverdi, A. (2016). content analysis of online consumer reviews: a case study on food \& beverage enterprises in Kuşadası. International Refereed Journal of Marketing and Market Researches, vol9, p. 1-22. Doi: 10.17369/UHPAD.2016923643.

Erbaş, E. (2019). Social business model and sharing economy for community based tourism development: A Case Study of Lisinia Doğa. Journal of Tourism and Gastronomy Studies, year 7, no. 4, vol 7, p. 2399-2417.

Hosany, S. \& Witham, M. (2009). Dimensions of cruisers' experiences, satisfaction, and intention to recommend. Journal of Travel Research, no. 3. Vol 49, p. 351-364.

İnanır, A. \& Ongun, U. (2019). A Study on the experience of tourists visiting Yeşilova Salda. Journal of Turkish Tourism Research, year 3, no. 4. Vol 3, p. 1028-1041. DOI: 10.26677/TR1010.2019.226.

İnanır, A., Uslu, A. \& Çaprak, D. (2019). Cittaslow and rural tourism: a research in Eğirdir District. Journal of Tourism and Gastronomy Studies, year 7, no. 3, vol 7, p. 1711-1726. DOI: 10.21325/jotags.2019.

Jackson, M.S., White, G.N. \& Schmierer, C.L. (1996). Tourism experiences within an attributional framework. Annals of Tourism Research, no. 3, vol 23, p. 798-810. 
Kesici, E., Kesici, K. \& Kesici, C. (2018). Sustainability of Lake Salda protected area, Voice of Nature, year 1, no. 1 , vol 1, p. 3-11.

Kim, W.G., Li, J.J. \& Brymer, R.A. (2016). The impact of social media rewievs on restaurand performance: the moderating role of excellence certificate. International Journal of Hospitality Management, vol 55, p. 41-51.

Li, Y. (2000). Geographical consciousness and tourism experience. Annals of Tourism Research, no. 7, vol 27, p. $863-83$.

McIntosh, A. \& A. Siggs (2005). An exploration of the experi-ential nature of boutique accommodation. Journal of Travel Research, no.1, vol 44, p. 74-81.

Oh, H., Fiore, A. \& Jeoung, M. (2007). Measuring experience economy concepts: tourism applications. Journal of Travel Research, no.2, vol 46, p. 119-32.

Ongun, U. (2017). An answer to changing tourism trends: rural tourism and Turkey's practices. The Journal of Kesit Academy, year 3, no.9, vol. 3, p. 131-143.

Ongun, U., Gövdere, B. \& Çiçek, U. (2016). The evaluation withth swot analysis of Yeşilova rural tourism potential. Suleyman Demirel University The Journal of Visionary, year 7, no. 16, vol 7, p. 75-88.

Ongun, U., Gövdere, B. \& Kaygısız, D.A. (2015). Rural tourism potential evaluation of Burdur Province: problems and solution proposals. Mehmet Akif Ersoy University Journal of Social Sciences Institute, year 7 , no. 12, vol 7, p. 99-116.

Page, S. (2005). Tourism and Transport Global Perspectives. Pearson Prentice Hall: London, U.K.

Pine, B.J. \& Gilmore, J.H. (1998). Welcome to the experience economy, Harvard Business Review, no. 4, vol 76, p. 96-105.

Plog, S. (2001). Why destinations areas rise and fall in popularity, an update of a cornel quarterly classic. Cornel Hotel and Administration Quarterly, year 11, no. 3, vol 42, p.13-24.

Prentice, R.C., Witt, S.F. \& Hamer, C. (1998). Tourism as experience: the case of Heritage Parks. Annals of Tourism Research, no. 1, vol 25, p. 1-24.

Polat, A.S. \& Polat, S. (2016). Socio-psychological analysis of alienation in tourism perspective: the alienation cycle from daily life to touristic life, Sosyoekonomi, year 12, no. 28, vol 24, p.235-253

Popp, L. \& McCole, D. (2016). Understanding tourists' itineraries in emerging rural tourism regions: the application of paper-based itinerary mapping methodology to a wine tourism region in Michigan. Current Issues in Tourism, year 18, no. 10, vol 19, p. 988-1004, DOI:10.1080/13683500.2014.942259.

Sağıroğlu, M. (2019). The perceptual change of reality in tourist places: authenticity in modern and post-modern tourism experiences. Journal of Planning, year 15, no. 2. Vol 29, p.:90-101.

Sert, M. Arsoy, Z. \& Çelik, M,Y. (2018). Characterization of rocks creating the strip of Lake Salda. Current Academic Studies in Engineering Sciences-2018, IVPE, p. 655-668.

Soykan, F. (2003). Rural tourism and its importance for Turkey Tourism. Journal of Aegean Geographical, year 12 , no. 1, vol 12, p. 1-11.

Soykan, F. (2001). A unique example of rural tourism for the Aegean Region: Şirince Village (Selçuk/İzmir). Maltepe University Journal of Vacational School, year 1, no, 2, vol 1, p. 151-176.

Temurçin, K., Atayeter, Y. \& Tozkoparan, U. (2019). Tourism potential of Lake Salda and its surroundings and its impact on socio-economic structure of Yeşilova District, SDU Faculty of Arts And Sciences Journal Of Social Sciences, no. 2, vol 47, p. 40-63.

Türkay, O., Kahraman, N. (2009). Tourism and Environment. Detay Yayıncılı, Ankara.

Uslu, A., Sancar, M. F., Akay, B. \& Kutukız, D. (2015). A research on rural tourism potential and educated students perception of rural tourism in Siirt City. Journal of Academic Outlook, year 12, no. 3, vol 49, p. 350-365.

Zhou, L. (2014). Online rural destination images: Tourism and rurality. Journal of Destination Marketing \& Management, year 3, no. 2, vol 3, p. 227-240.

*** Burdur Provincial Directorate of Culture and Tourism (2020). https://burdur.ktb.gov.tr/ Eklenti/64088,burdur-turizm-istatistikleri- $\quad$ 2019pdf.pdf? accessed 18.01.2020.

*** Burdur Provincial Directorate of Culture and Tourism (2011). Burdur Province Publicity Guide. http://www.burdurkulturturizm.gov.tr/Eklenti/45961,burdurrehberturk.pdf? Access Date: 10.12.2019.

*** Ministry of Culture and Tourism (2019). Statistics and data. https://yigm.ktb.gov.tr/TR-201826/yillikbultenler.html, accessed 30.12.2019.

*** World Tourism Organization (2004). Rural tourism in Europe: Experiences, development and perspectives. e-unwto.org/doi/book/10.18111/9789284407163.

https://www.sabah.com.tr/galeri/turizm/burdurda-dogal-yasam-koyu-lisiniaya, accessed 10.01.2019.

https:// www.lisinia.com/tr/projeler.html, accessed 10.01.2019.

http://www.tripadvisor.com.tr/Attraction_Review-g781298-d4191422-Reviews-Salda_Golu_Burdur_Province. html, accessed 01.11.2019.

http://www.tourismtheories.org/?p=1503, accessed 27.02.2019.

Submitted:

30.01.2020
Revised:

07.04.2020
Accepted and published online 14.04.2020 